\title{
Penerapan Model Discovery Learning UnTUK MeningkatKan KETERAMPILAN BERPIKIR KRITIS SISWA KelAS X PADA MATERI KALOR
}

\author{
U. Elly Sapitri ${ }^{1)}$, Yudi Kurniawan ${ }^{2)}$, Emi Sulistri ${ }^{3)}$ \\ ${ }^{1)}$ STKIP Singkawang, Singkawang, Indonesia \\ 1) E-mail: urayellysapitri@gmail.com \\ ${ }^{2)}$ Prodi Pendidikan Fisika STKIP Singkawang \\ E-mail: yudikurniawan1012@gmail.com \\ ${ }^{3)}$ Prodi Pendidikan Fisika STKIP Singkawang \\ E-mail: sulistriemi@gmail.com
}

\begin{abstract}
Abstrak. Penelitian ini bertujuan untuk mendapatkan gambaran mengenai keterampilan berpikir kritis siswa membuat keputusan, membandingkan dan memecahkan masalah pada materi kalor dengan diterapkan model Discovery Learning. Penelitian ini merupakan penelitian kuantitatif dan sampel diambil dengan menggunakan teknik cluster random sampling dengan jumlah sampel 20 siswa kelas X di salah satu SMA di kota Singkawang. Untuk mencapai tujuan tersebut, siswa telah mengisi pertanyaan mengenai materi kalor pada tes yang berbentuk tes uraian. Hasil penelitian menunjukkan bahwa model Discovery Learning dapat meningkatan keterampilan berpikir kritis siswa yaitu pada indikator membuat keputusan dengan skor $\mathrm{N}$-gain 0,37 dengan kategori sedang, indikator membandingkan dengan skor $\mathrm{N}$-gain 0,39 dengan kategori sedang, indikator pemecahan masalah dengan skor $\mathrm{N}$-gain 0,33 dengan kategori sedang.Hasil penelitian ini bisa menjadi referensi bagi peneliti masa depan untuk meningkatkan keterampilan berpikir kritis siswa.
\end{abstract}

Kata Kunci: Model Discovery Learning, Keterampilan Berpikir Kritis, Kalor

\section{Pendahuluan}

Fisika merupakan salah satu cabang IPA yang mendasari perkembangan teknologi maju dan konsep hidup harmonis dengan alam. Sebagai ilmu yang mempelajari fenomena alam, fisika juga memberikan pelajaran yang baik kepada manusia untuk hidup selaras berdasarkan hukum alam. Pengelolaan sumber daya alam dan lingkungan serta pengurangan dampak bencana alam tidak akan berjalan secara optimal tanpa pemahaman yang baik tentang fisika [1].

Berpikir kritis merupakan cara berpikir dimana seseorang mengikuti langkah-langkah yang sistematis dan logis. Pikiran yang logis artinya suatu jalan pikiran yang tepat dan jitu sesuai dengan patokan-patokan yang dikemukakan dalam logika [2]. Hanya sedikit sekolah yang benarbenar mengajar untuk berpikir kritis [3]. Sekolah hanya menghabiskan waktu yang banyak untuk membuat siswa memberikan jawaban yang benar dengan cara meniru daripada mendorong siswa untuk memperluas pemikiran mereka dengan membuat ide-ide baru sebelum membuat kesimpulan. Dalam proses pembelajaran fisika guru masih cenderung menggunakan pembelajaran yang informatif, seperti pembelajaran masih menggunakan metode ceramah dan hanya memberikan tugas setelah menjelaskan materi [4]. Tugas yang diberikan langsung dikerjakan oleh siswa dan dikumpulkan tanpa membahas hasil tugas yang dikerjakan siswa dikarenakan tidak cukupnya waktu untuk membahas tugas tersebut, sehingga siswa tidak mengetahui apakah tugas yang dikerjakan siswa benar atau salah. Proses pembelajaran ini membuat siswa menjadi pasif dan malas untuk berpikir terhadap apa yang telah dikerjakan siswa.

Permasalahan tersebut harus diselesaikan, agar keterampilan berpikir kritis siswa dapat dikembangkan atau ditingkatkan. Salah satu solusi yang tepat untuk menyelesaikan permasalahan tersebut adalah dengan memilih salah satu model pembelajaran yang tepat dalam melatihkan keterampilan berpikir kritis siswa. Model pembelajaran yang efektif sebagai salah satu upaya untuk melatih siswa agar memiliki keterampilan berpikir kritis yaitu dengan di 
terapkannya model Discovery Learning. Model Discovery Learning adalah pembelajaran dimana guru memberikan suatu kebebasan pada siswa untuk menemukan sesuatu sendiri, sehingga siswa akan sampai pada suatu pengalaman dan membantu siswa mengungkapkan ide mereka bersama dan memperbaiki pemahaman pada saat diberi tugas ataupun melakukan percobaan. Penelitian ini bertujuan untuk menggambarkan siswa agar mampu membuat keputusan, membandingkan, memecahkan masalah pada materi kalor sehingga dapat melatihkan keterampilan berpikir kritis.

Berpikir kritis merupakan salah satu keterampilan berpikir tingkat tinggi (higher order thinking). Berpikir kritis adalah sebuah proses terorganisasi yang memungkinkan siswa mengevaluasi bukti, asumsi, logika, dan bahasa yang mendasari pemikiran orang lain [5].

Berpikir tingkat tinggi menurut Marzano dalam mengidentifikasi 13 keterampilan berpikir tingkat tinggi, yaitu membandingkan, mengklasifikasikan, penalaran induktif (menyimpulkan induktif), penalaran deduktif (menyimpulkan deduktif), menganalisis kesalahan, membangun dukungan, menganalisis percobaan, abstrak, membuat keputusan, penyelidikan, pemecahan masalah, penyelidikan percobaan, dan penemuan. Indikator yang diambil dari berpikir tingkat tinggi untuk melatihkan berpikir kritis yaitu indikator membuat keputusan, membandingkan dan pemecahan masalah [6].

Discovery Learning (DL) adalah teori belajar yang didefinisikan sebagai proses pembelajaran yang terjadi bila siswa tidak disajikan dengan pelajaran dalam bentuk finalnya, tetapi diharapkan mengorganisasi sendiri, misalnya dalam melakukan eksperimen atau percobaan. Model DL menekankan pada ditemukannya konsep atau prinsip yang sebelumnya tidak diketahui, masalah yang dihadapkan kepada siswa semacam masalah yang direkayasa oleh guru dan materi yang akan disampaikan tidak disampaikan dalam bentuk final akan tetapi siswa didorong untuk mengidentifikasi apa yang ingin diketahui, dan dilanjutkan dengan mencari informasi sendiri kemudian mengorganisasi atau membentuk (konstruktif) apa yang mereka ketahui dan mereka pahami dalam

suatu bentuk akhir [7]. Penggunaan model DL ingin merubah kondisi belajar yang pasif menjadi aktif, mengubah pembelajaran yang teacher oriented ke student oriented.

\section{METODE}

Penelitian ini merupakan penelitian kuantitatif dan sampel diambil dengan menggunakan teknik cluster random sampling dengan jumlah sampel 20 siswa di salah satu SMA di kota Singkawang. Teknik yang akan digunakan dalam penelitian adalah teknik pengukuran menggunakan tes. Tes yang digunakan adalah tes uraian yang untuk mengetahui keterampilan berpikir kritis siswa pada indikator membuat keputusan, membandingkan, dan pemecahan masalah.

\section{HASIL DAN PEMBAHASAN}

Hasil penelitian ini berupa keterampilan berpikir kritis siswa pada materi kalor dengan menggunakankategori dari kriteria $\mathrm{N}$-gain sebagai berikut.

TABLE I

KATEGORI INDIKATOR KETERAMPILAN BERPIKIR KRITIS BERDASARKAN NGAIN

\begin{tabular}{cc}
\hline Skor N-gain & Kriteria \\
\hline$<g>\geq 0,7$ & Tinggi \\
$0,3 \leq<g><0,7$ & Sedang \\
$<g><0,3$ & Rendah \\
\hline
\end{tabular}

Tabel.1 menyatakan kriteria keterampilan berpikir kritis siswa. Berikut data hasil keterampilan berpikir kritis siswa pada materi kalor.

Berdasarkan Gambar.1 dinyatakan untuk Indikator keterampilan berpikir kritis membuat keputusan mengalami peningkatan sebesar 0,37 dengan kategori sedang, kategori sedang disebabkan kemampuan siswa untuk menentukan kriteria dari masalah yang diberikan cukup baik dibanding sebelum diterapkan model DL. Indikator membandingkan mengalami peningkatan sebesar 0,39 dengan kategori sedang, kategori sedang disebabkan kurangnya kemampuan siswa untuk mengidentifikasi dan mengutarakan persamaan atau perbedaan dari masalah yang diberikan. Indikator pemecahan masalah mengalami peningkatan sebesar 0,33 dengan 


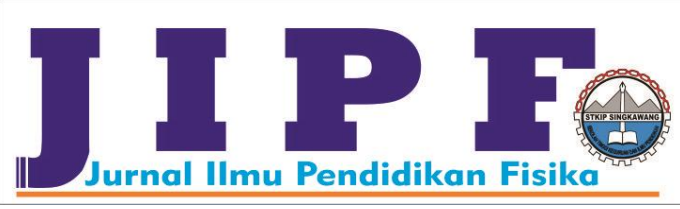

kategori sedang, kategori sedang disebabkan kemampuan siswa memberikan solusi untuk fenomena atau masalah yang diberikan kurang dilatihkan dalam pembelajaran sebelumnya, terutama pada saat diberikan tugas, tugas tersebut langsung dikerjakan oleh siswa dan dikumpulkan tanpa membahas hasil tugas yang dikerjakan siswa, sehingga siswa tidak mengetahui apakah tugas yang dikerjakan siswa benar atau salah. Dari hasil yang diperoleh dinyatakan bahwa rata-rata hasil dari keterampilan berpikir kritis siswa diperoleh peningkatan dengan kategori sedang karena $0,3 \leq<g><0,7$.

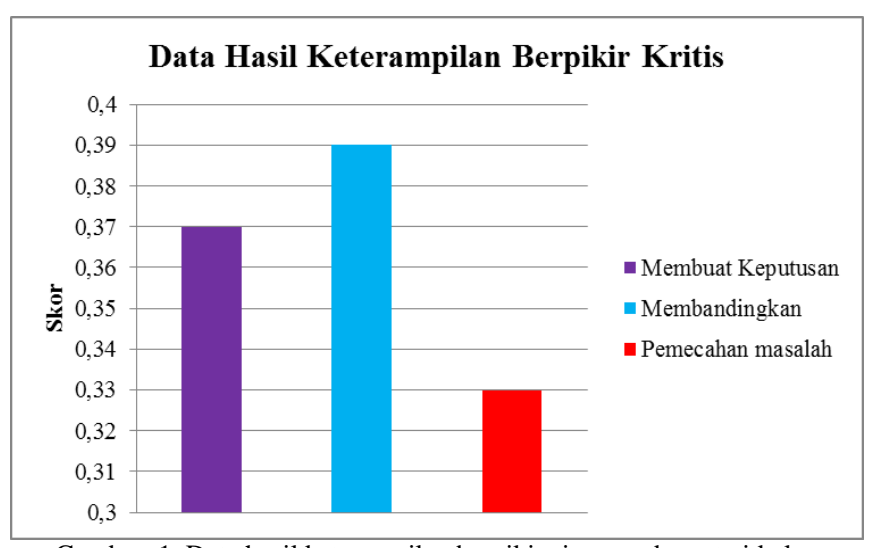

Gambar. 1 Data hasil keterampilan berpikir siswa pada materi kalor

\section{KESIMPULAN DAN SARAN}

Berdasarkan hasil analisis data yang diperoleh dari hasil tes yang diberikan pada siswa, rata-rata hasil keterampilan berpikir kritis siswa setelah ternormalisasi dengan menggunakan uji $\mathrm{N}$-gain pada indikator membuat keputusan sebesar 0,37; membandingkan sebesar 0,39; pemecahan masalah sebesar 0,33. Hasil dari keterampilan berpikir

kritis siswa diperoleh peningkatan dengan kategori sedang pada rentang $0,3 \leqslant<\mathrm{g}><0,7$. Diharapkan hasil dari penelitian ini dapat dijadikan referensi untuk penelitian selanjutnya dan dapat untuk meningkatkan keterampilan berpikir kritis siswa.

\section{DAFTAR PUSTAKA}

[1] Permendiknas No 22 tahun 2006. Tentang Standar Isi Pendidikan Dasar dan Menengah. Jakarta.Hake, Richard R. 1999. Analyzing Change/Gain Scores. Dept. Of Physics Indian.

[2] Srianty, Samad., Abdul dan Patandean, A. J. 2011. Upaya Meningkatkan Kemampuan Berpikir Kritis Fisika Siswa Kelas XI IPA3 SMA Negeri 1 Bungoro Melalui Model Pembelajaran Generatif. Jurnal Jurusan Fisika Universitas Negeri Makassar. Vol.7 No. 1 : 1-12

[3] Santrock, John W. 2014. Psikologi Pendidikan. Salemba Humanika: Jakarta.

[4] Suryadana, Brian Aziz., Suprihati, Tjiptaning dan Astutik, Sri. 2012 Penerapan Model Kooperatif Tipe Group Investigation (GI) disertai Media Kartu Masalah Pada Pembelajaran Fisika Di SMA. Jurnal Pembelajaran Fisika, Universitas Jember. Vol. 1 No. 3.

[5] Rofiah, Emi., Aminah, Nonoh Siti dan Ekawati, Elvin Yusliana. 2013. Penyusunan Instrumen Tes Kemampuan Berpikir Tingkat Tinggi Fisika pada Siswa SMP. Jurnal Pendidikan Fisika. Vol.1 No. 2: 17.

[6] Heong, Yee Mei, et.all., 2011. The Level of Marzano Higher Order Thinking Skills among Technical Education Student. International journal of Social Science and Humanity. Vol. 1. No. 2 : 1-5.

[7] Kementrian Pendididikan dan Kebudayaan. (2014). Model Pembelajaran Penemuan (Discovery Learning). 